Trinity University

Digital Commons @ Trinity

Health Care Administration Faculty Research

Health Care Administration

$7-2002$

\title{
A Note on Job Mobility Among Workers with Disabilities
}

\author{
Marjorie L. Baldwin \\ Edward J. Schumacher \\ TrinityUniversity, eschumac@trinity.edu
}

Follow this and additional works at: https://digitalcommons.trinity.edu/hca_faculty

Part of the Medicine and Health Sciences Commons

\section{Repository Citation}

Baldwin, M.L. \& Schumacher, E.J. (2002). A note on job mobility among workers with disabilities. Industrial Relations: A Journal of Economy and Society, 41(3), 430-441. doi: 10.1111/1468-232X.00255

This Article is brought to you for free and open access by the Health Care Administration at Digital Commons @ Trinity. It has been accepted for inclusion in Health Care Administration Faculty Research by an authorized administrator of Digital Commons @ Trinity. For more information, please contact jcostanz@trinity.edu. 


\title{
A Note on Job Mobility Among Workers with Disabilities
}

\author{
MARJORIE L. BALDWIN and EDWARD J. SCHUMACHER*
}

\begin{abstract}
This article uses data from the 1990 and 1993 panels of the Survey of Income and Program Participation to analyze relationships between disability status and job mobility. We identify individuals who experienced voluntary or involuntary job separations over a 20-month period and examine the effect of disability status on rates of job change and wage growth following a job change. The results show that disabled workers are more likely to experience involuntary job changes than are nondisabled workers, but there is little difference in the wage effects of job changes by disability status.
\end{abstract}

IN THE YEARS FOLLOWING PASSAGE OF THE AMERICANS WITH DisAbiLities ACT (ADA), complaints of employment and wage discrimination against workers with disabilities increased rapidly. There is no empirical evidence, however, documenting differences in the rates of job separations between disabled and nondisabled workers.

This article uses data from the 1990 and 1993 panels of the Survey of Income and Program Participation (SIPP) to analyze relationships between disability status, job changes, and wages. We track employment histories across six waves of data to identify individuals who experienced a job separation during a 20-month period. The data are rich enough to distinguish between voluntary (worker-initiated) and involuntary (employer-initiated)

*Department of Economics, East Carolina University, Greenville, NC. E-mail:ecbaldwi@mail. ecu.edu. This research was supported, in part, by a grant from the Northwestern/University of Chicago Joint Center for Poverty Research. We appreciate helpful comments from William G. Johnson, Barry Hirsch, Thomas DeLeire, Jill Tiefenthaler, Amy Gibson, and anonymous referees. Any remaining errors are our own.

Industrial Relations, Vol. 41, No. 3 (July 2002). (C) 2002 Regents of the University of California Published by Blackwell Publishing, Inc. 350 Main Street, Malden, MA 02148, USA, and 108 Cowley Road, Oxford, OX4 IJF, UK. 
job separations. Using the SIPP data, we compare the relative job mobility of disabled and nondisabled workers across four dimensions.

Workers with disabilities are expected to have higher rates of involuntary job changes than do nondisabled workers. Employers generally face greater uncertainties in hiring decisions involving disabled workers than in decisions regarding nondisabled workers. If employers underestimate the effects of functional limitations on worker productivity, this may lead to a higher rate of job terminations for the disabled group. Finding a good job match is also difficult for workers with disabilities. Once a good match has been found (in terms of job accommodations, nonwage benefits, etc.), a disabled worker may be reluctant to leave voluntarily, leading to a higher proportion of involuntary job separations among workers with disabilities. Finally, discriminatory employers may regard workers with disabilities as marginal workers who are "last hired, first fired."

The effect of disability on rates of voluntary job changes is unknown. Functional limitations or the fear of losing health insurance may constrain the mobility of disabled workers, making it difficult or impossible to search for a new job. Discrimination by employers, employees, or customers of other firms may reduce the number of incoming wage offers to disabled workers, also reducing their prospects for voluntary job changes. On the other hand, disabled workers, as well as employers, face uncertainties in evaluating the effects of functional limitations on productivity. If workers initially overestimate their functional capacities, conditional on their impairments, this may lead to higher rates of voluntary turnover. Disabled workers also have potential alternative sources of income (SSDI and SSI) that are unavailable to nondisabled workers and lower the expected costs of job separations, thereby increasing expected turnover rates.

Wage growth following an involuntary job change could be greater or smaller for workers with disabilities than for nondisabled workers. Disabled workers have a lower probability of receiving high wage offers than do nondisabled workers because of employer discrimination and difficulties in searching for new jobs, so their postdisplacement wage losses may be greater. On the other hand, disabled workers have sources of income unavailable to nondisabled workers (disability pensions, SSDI, and SSI), so those who remain in the labor market may be a selected sample with the highest wage offers.

Likewise, the effect of disability on wage growth following a voluntary job change is an empirical question. Disabled workers are expected to receive lower wage offers than nondisabled workers because of discrimination, limitations on job search and difficulties in evaluating the effects of functional limitations on productivity. In addition, disabled workers may be forced to leave higher-paid jobs because they have overestimated their 


\section{2 / Marjorie L. BAldwin And Edward J. Schumacher}

productivity or are no longer able to perform the required tasks. Both hypotheses suggest that wage growth will be slower following a voluntary job change for disabled workers than for nondisabled workers. On the other hand, disabled workers may demand relatively high wage offers before they are willing to make a voluntary job change to compensate for greater uncertainty in finding a good match. These selection effects would cause us to observe faster wage growth among disabled workers because only those workers with the highest wage offers change jobs voluntarily.

\section{Data and Methods}

We provide empirical evidence on job mobility and wage growth by disability status using data from the 1990 and 1993 panels of the SIPP. Each wave, or interview, refers to a 4-month reference period. We use wave 3 as the start point for the study because it includes questions about functional limitations and disability status. Persons are considered disabled if they indicate that a health condition "limits their ability to work at a job or around the house" or "limits their mobility or ability to communicate."

The sample is restricted to persons aged 16 to 65 years who are employed during the final month of the wave 3 reference period (hereafter called the start date) and have continuous data on employment and earnings through wave 8 (a 20-month period). After exclusions, there are 1445 (1293) disabled and 15,982 (12,734) nondisabled persons in the 1990 (1993) sample. ${ }^{1}$

Workers who experience a job change at any time in the 20-month observation period are classified as job changers; workers who do not experience a job change are classified as job stayers. Job changers are further classified as voluntary changers, those who leave their job for a new job, retirement, or other unspecified reasons and involuntary changers, those who are laid off, discharged, or work in a temporary job that ended. ${ }^{2}$

\footnotetext{
${ }^{1}$ Excluded are self-employed persons, persons who receive Social Security disability benefits (because the program places restrictions on their labor market participation), and persons in the armed forces or construction occupations (because job changes are difficult to define in these occupations). In the 1990 panel, 75 percent of eligible workers at the start date in wave 3 have complete data through wave 8 (70 percent of disabled workers, 75 percent of nondisabled workers); in the 1993 panel, 72 percent have complete data through wave 8 ( 68 percent of disabled workers, 73 percent of nondisabled workers).

${ }^{2}$ There may be misclassification errors because some disabled workers report an involuntary layoff when they are actually quitting for noneconomic reasons or because some disabled workers report a separation for "other" (health) reasons when they are actually being terminated. Such errors in reporting may occur among nondisabled workers as well.
} 
Job-Change Model. We estimate a multinomial logit model of the decision to change jobs to analyze the relative mobility of disabled and nondisabled workers. The dependent variable classifies workers as voluntary job changers, involuntary job changers, or job stayers.

Independent variables in the model control for demographic characteristics (male, married, African-American), human capital characteristics (education, job experience), job-related characteristics (union member, parttime worker, public-sector worker, industry, and occupation), labor market characteristics (metropolitan statistical area, region), and nonwage income (total family nonwage income in the 4-month reference period preceding the start date). The model also includes binary variables to identify workers with disabilities and workers whose fringe benefits include employerprovided health insurance or pension coverage (defined benefit, defined contribution, and other type of pension). We estimate one version of the model for the pooled sample from 1990 and 1993 (with a year dummy) and another version separately by year.

Wage-Change Model. We estimate a variation of the model studied by Ruhm (1991), who examined the effects of job displacement on the earnings and employment of all workers. The equation to be estimated is

$$
\Delta W_{i}=Y_{i} \alpha_{1 i}+C_{i} \alpha_{2 i}+\gamma_{1} D_{i}+\gamma_{2}\left(D_{i} \times C_{i}\right)+e_{i}
$$

where $\Delta W$ is the change in the log wage between the start date and end date (month 20), $Y$ is a vector of variables measuring changes in observable characteristics over the 20-month period with coefficient vector $\alpha_{1}$, and $C$ is a vector of two binary variables identifying voluntary and involuntary job changers with coefficient vector $\alpha_{2}$. The remaining variables in the wage equation are the disabled dummy $D$ and the interaction terms between disability status and the job-change variables. Variables in the vector $Y$ include change in experience squared, change in marital status, and change in spouse's employment status.

The wage-change model is estimated with the pooled sample in a model that includes a year dummy and separately for the 2 years. The samples are restricted to persons who are employed in both waves 3 and $8(15,909$ workers in 1990 and 13,059 in 1993).

\section{Results}

There is slightly greater job mobility among disabled workers than among nondisabled workers and slightly greater mobility in 1990 than in 


\section{4 / Marjorie L. Baldwin and Edward J. Schumacher}

1993. In 1990, 22 percent of disabled workers and 18 percent of nondisabled workers left their jobs during the 20-month period. In 1993, the proportions of job changers decreased to 20 and 16 percent. Among workers who changed jobs, approximately 40 percent were involuntary job changers. The proportion of involuntary changers declined between 1990 and 1993, dropping 9 percentage points for nondisabled workers and 2 percentage points for disabled workers.

Logit Estimates of the Job-Change Models. Table 1 presents results for the multinomial logit models of job changes. Consistent with our prediction, the results from the pooled sample indicate that disabled workers are significantly more likely to make involuntary job changes than are nondisabled workers. ${ }^{3}$ All else equal, a disabled worker is 2.7 percent more likely to experience an involuntary job change than is a nondisabled worker relative to the mean change rate of about 17 percent. The rate of involuntary job changes for the entire sample is 7.1 percent, so this represents a 38 percent increase in the rate of involuntary job changes for workers with disabilities relative to nondisabled workers.

When the job-change model is estimated separately for 1990 and 1993, we find that the rates of involuntary job changes are significantly higher for disabled workers than for nondisabled workers in both years, but the effect is stronger in 1990. In 1993, disabled workers were only 1.6 percent more likely to experience an involuntary job change than were nondisabled workers relative to the mean change rate of 16 percent.

The results are consistent with either the job-mismatch hypothesis (employers have difficulty evaluating the productivity of disabled workers and are more likely to make mistakes that lead to terminations; disabled workers have difficulty finding good job matches and are reluctant to leave voluntarily, leading to a higher proportion of involuntary changes) or the discrimination hypothesis (employer prejudice against workers with disabilities leads to a higher rate of job terminations). One might speculate that the changes between 1990 and 1993 reflect the impact of the ADA. If employers are threatened by the possibility of legal action and complaints to the Equal Employment Opportunity Commission (EEOC), discrimination against workers with disabilities in job terminations and layoffs should decrease, consistent with our finding that, all else equal, the difference in rates of involuntary job changes between disabled and nondisabled workers

\footnotetext{
${ }^{3}$ We estimated a binomial probit model with outcomes change jobs/do not change jobs with similar results. The pooled model indicates that workers with disabilities are about 4 percent more likely to change jobs than are nondisabled workers. Results are available from the authors.
} 
declined over the period. However, we stratified our samples of disabled workers into groups with conditions subject to more and less prejudice and found no evidence that the rates of involuntary job changes were positively correlated with prejudice, as the discrimination hypothesis would suggest. ${ }^{4}$

There is no statistical difference in the probability of disabled or nondisabled workers making voluntary job changes in the pooled job-change model or in the model estimated with data from 1990, but in 1993 disabled workers were significantly more likely than nondisabled workers to make voluntary job changes. All else equal, a disabled worker is 1.1 percent more likely to make a voluntary job change relative to the mean change rate of 16 percent. The rate of voluntary job changes in the 1993 sample is 10 percent, so this represents an 11 percent increase in the rate for disabled workers.

The fact that we found no significant differences in the rates of voluntary turnover in two of our three models is not surprising because the predicted relationship between disability status and voluntary job changes is ambiguous. Limitations on job search, fear of losing health insurance, and discrimination by potential new employers are expected to reduce the rate of voluntary turnover among disabled workers relative to nondisabled workers. On the other hand, job mismatch and the availability of disability benefit programs are expected to increase the rate of voluntary turnover among disabled workers. ${ }^{5}$

The significantly higher rate of voluntary turnover for disabled workers in 1993 suggests that something changed in the labor market for workers with disabilities over the period. One obvious explanation is that the antidiscrimination provisions of the ADA created opportunities for disabled workers to move voluntarily to better jobs. Another explanation

\footnotetext{
${ }^{4}$ See Royal and Roberts (1987) and Westbrook, Legge, and Pennay (1993) for rankings of negative attitudes (prejudice) toward persons with different health conditions. Baldwin and Johnson (2000) report larger unexplained wage differentials between nondisabled workers and workers with health conditions subject to more prejudice (MP) than between nondisabled workers and workers with conditions subject to less prejudice (LP). Their results support the hypothesis that workers with disabilities are subject to employer wage discrimination. Following Baldwin and Johnson (2000), we stratified our samples of workers with disabilities into LP and MP groups and reestimated the pooled job-change model with dummies for each group. Contrary to the discrimination hypothesis, the results show that LP workers have a significantly higher probability of involuntary job changes than do nondisabled workers, but there is no significant difference between the probabilities of involuntary changes for the nondisabled and MP groups.

${ }^{5}$ According to the job-match hypothesis, disabled workers will search longer, on average, to find good job matches and may change jobs often, at first, until a good match is found. After a match is found, disabled workers are less likely to change jobs voluntarily. This implies that voluntary job changes should decrease faster with job tenure for the disabled. To test this prediction, we reestimated the jobchange model with an interaction term between job experience and disability status. The coefficient of the interaction term was not significant, so we found no specific evidence to support the job-match story in our data.
} 
TABLE 1

Multinomial Logit Analysis of Reasons for Job Changes

\begin{tabular}{|c|c|c|c|c|c|c|}
\hline \multirow[b]{2}{*}{ Variables $^{a}$} & \multicolumn{2}{|c|}{1990 and $1993^{b}$} & \multicolumn{2}{|c|}{1990 Only $^{b}$} & \multicolumn{2}{|c|}{1993 Only $^{b}$} \\
\hline & $\begin{array}{l}\text { Voluntary } \\
(N=3263)\end{array}$ & $\begin{array}{l}\text { Involuntary } \\
(N=2222)\end{array}$ & $\begin{array}{l}\text { Voluntary } \\
(N=1811)\end{array}$ & $\begin{array}{l}\text { Involuntary } \\
(N=1427)\end{array}$ & $\begin{array}{l}\text { Voluntary } \\
(N=1452)\end{array}$ & $\begin{array}{l}\text { Involuntary } \\
(N=795)\end{array}$ \\
\hline Disabled & $\begin{array}{c}0.131 \\
(0.101) \\
{[0.005]}\end{array}$ & $\begin{array}{l}0.356^{* *} \\
(0.088) \\
{[0.027]}\end{array}$ & $\begin{array}{c}-0.144 \\
(0.101) \\
{[0.007]}\end{array}$ & $\begin{array}{c}0.327 * * \\
(0.089) \\
{[0.025]}\end{array}$ & $\begin{array}{c}0.301^{*} \\
(0.119) \\
{[0.011]}\end{array}$ & $\begin{array}{c}0.234^{*} \\
(0.098) \\
{[0.016]}\end{array}$ \\
\hline Health insurance & $\begin{array}{c}-0.584^{* *} \\
(0.054) \\
{[-0.028]}\end{array}$ & $\begin{array}{c}-0.417 * * \\
(0.046) \\
{[-0.030]}\end{array}$ & $\begin{array}{c}-0.599 * * \\
(0.069) \\
{[-0.034]}\end{array}$ & $\begin{array}{c}-0.540^{* *} \\
(0.064) \\
{[-0.039]}\end{array}$ & $\begin{array}{c}-0.578^{* *} \\
(0.089) \\
{[-0.021]}\end{array}$ & $\begin{array}{c}-0.327 * * \\
(0.069) \\
{[-0.022]}\end{array}$ \\
\hline Pension coverage & $\begin{array}{c}-0.927 * * \\
(0.060) \\
{[-0.043]}\end{array}$ & $\begin{array}{c}-0.831 * * \\
(0.050) \\
{[-0.060]}\end{array}$ & $\begin{array}{c}-0.654^{* *} \\
(0.075) \\
{[-0.038]}\end{array}$ & $\begin{array}{c}-0.378^{* *} \\
(0.068) \\
{[-0.026]}\end{array}$ & $\begin{array}{c}-1.388^{* *} \\
(0.104) \\
{[-0.048]}\end{array}$ & $\begin{array}{c}-1.373^{* *} \\
(0.077) \\
{[-0.095]}\end{array}$ \\
\hline Job experience & $\begin{array}{c}-0.048^{* *} \\
(0.005) \\
{[-0.002]}\end{array}$ & $\begin{array}{c}-0.019 * * \\
(0.004) \\
{[-0.001]}\end{array}$ & $\begin{array}{c}-0.051^{* *} \\
(0.006) \\
{[-0.003]}\end{array}$ & $\begin{array}{r}-0.026^{*} \\
(0.005) \\
{[-0.002]}\end{array}$ & $\begin{array}{c}-0.044 * * \\
(0.008) \\
{[-0.002]}\end{array}$ & $\begin{array}{c}-0.014^{* *} \\
(0.005) \\
{[-0.001]}\end{array}$ \\
\hline Male & $\begin{array}{l}0.204^{* *} \\
(0.053) \\
{[0.011]}\end{array}$ & $\begin{array}{c}-0.158^{* *} \\
(0.044) \\
{[-0.013]}\end{array}$ & $\begin{array}{c}0.151^{*} \\
(0.066) \\
{[0.010]}\end{array}$ & $\begin{array}{c}-0.195^{* *} \\
(0.060) \\
{[-0.016]}\end{array}$ & $\begin{array}{l}0.297 * * \\
(0.087) \\
{[0.011]}\end{array}$ & $\begin{array}{r}-0.107 \\
(0.066) \\
{[-0.009]}\end{array}$ \\
\hline Education & $\begin{array}{c}-0.011 \\
(0.010) \\
{[-0.001]}\end{array}$ & $\begin{array}{l}0.024 * * \\
(0.009) \\
{[0.002]}\end{array}$ & $\begin{array}{r}-0.015 \\
(0.013) \\
{[-0.001]}\end{array}$ & $\begin{array}{c}0.010 \\
(0.012) \\
{[0.001]}\end{array}$ & $\begin{array}{c}0.003 \\
(0.018) \\
{[0.000]}\end{array}$ & $\begin{array}{l}0.045^{* *} \\
(0.014) \\
{[0.003]}\end{array}$ \\
\hline Black & $\begin{array}{r}-0.056 \\
(0.086) \\
{[-0.001]}\end{array}$ & $\begin{array}{c}-0.455^{* *} \\
(0.084) \\
{[-0.035]}\end{array}$ & $\begin{array}{c}-0.025 \\
(0.103) \\
{[0.002]}\end{array}$ & $\begin{array}{c}-0.581 * * \\
(0.112) \\
{[-0.045]}\end{array}$ & $\begin{array}{r}-0.124 \\
(0.161) \\
{[-0.004]}\end{array}$ & $\begin{array}{r}-0.244 \\
(0.128) \\
{[-0.017]}\end{array}$ \\
\hline
\end{tabular}




\begin{tabular}{|c|c|c|c|c|c|c|}
\hline MSA $>100,000$ & $\begin{array}{c}-0.080 \\
(0.049) \\
{[-0.004]}\end{array}$ & $\begin{array}{c}-0.047 \\
(0.042) \\
{[-0.003]}\end{array}$ & $\begin{array}{c}-0.116 \\
(0.062) \\
{[0.007]}\end{array}$ & $\begin{array}{c}-0.052 \\
(0.056) \\
{[-0.003]}\end{array}$ & $\begin{array}{c}-0.005 \\
(0.082) \\
{[-0.000]}\end{array}$ & $\begin{array}{r}-0.041 \\
(0.062) \\
{[-0.003]}\end{array}$ \\
\hline Part time & $\begin{array}{c}-0.127^{*} \\
(0.064) \\
{[0.006]}\end{array}$ & $\begin{array}{r}-0.045 \\
(0.051) \\
{[-0.003]}\end{array}$ & $\begin{array}{r}-0.202^{*} \\
(0.083) \\
{[-0.012]}\end{array}$ & $\begin{array}{c}-0.041 \\
(0.069) \\
{[-0.002]}\end{array}$ & $\begin{array}{c}-0.003 \\
(0.102) \\
{[-0.000]}\end{array}$ & $\begin{array}{r}-0.048 \\
(0.078) \\
{[-0.003]}\end{array}$ \\
\hline Union member & $\begin{array}{c}0.056 \\
(0.073) \\
{[0.004]}\end{array}$ & $\begin{array}{r}-0.148^{*} \\
(0.068) \\
{[-0.012]}\end{array}$ & $\begin{array}{c}-0.008 \\
(0.091) \\
{[0.001]}\end{array}$ & $\begin{array}{c}-0.336^{* *} \\
(0.093) \\
{[-0.026]}\end{array}$ & $\begin{array}{c}0.177 \\
(0.127) \\
{[0.007]}\end{array}$ & $\begin{array}{c}0.044 \\
(0.101) \\
{[0.003]}\end{array}$ \\
\hline Married & $\begin{array}{c}-0.232^{* *} \\
(0.052) \\
{[-0.012]}\end{array}$ & $\begin{array}{r}-0.056 \\
(0.045) \\
{[-0.003]}\end{array}$ & $\begin{array}{c}-0.180^{* *} \\
(0.065) \\
{[-0.011]}\end{array}$ & $\begin{array}{c}-0.053 \\
(0.060) \\
{[-0.003]}\end{array}$ & $\begin{array}{c}-0.313^{* *} \\
(0.087) \\
{[-0.012]}\end{array}$ & $\begin{array}{r}-0.053 \\
(0.068) \\
{[-0.003]}\end{array}$ \\
\hline Year 1993 & $\begin{array}{c}-0.383^{* *} \\
(0.051) \\
{[-0.020]}\end{array}$ & $\begin{array}{c}0.026 \\
(0.041) \\
{[0.004]}\end{array}$ & - & - & - & - \\
\hline
\end{tabular}

${ }^{a}$ Other variables included in the equation are three regional dummies (representing four regions), publicsector employment, family income, eleven industry dummies, and five occupation dummies. The pooled (1990-1993) model also includes an interaction term between disability status and year. The omitted group is job stayers.

${ }^{b}$ Standard errors are shown in parentheses; marginal effects in brackets. In 1990, there are $1126(13,063)$ job stayers, $186(1625)$ voluntary changers, and 133 (1294) involuntary changers in the disabled (nondisabled) sample. In 1993, there are $1035(10,745)$ job stayers, 155 (1297) voluntary changers, and 103 (692) involuntary changers in the disabled (nondisabled) sample. Means for independent variables are available from the authors.

* Significance at the 0.05 level or better.

**Significance at the 0.01 level or better

SOURCE: SIPP, 1990 and 1993 (waves III-VIII). 


\section{8 / Marjorie L. Baldwin and Edward J. Schumacher}

is that increasing numbers of disabled workers left the job market to enter the disability rolls. Between 1991 and 1993, the average annual rate of increase in numbers of SSDI beneficiaries was 7.4 percent, compared with an average annual rate of increase of 2.6 percent between 1988 and 1990 (Social Security Administration 2001). The change in relative rates of voluntary turnover observed in our data is consistent with the story that after 1990, increasing numbers of more severely disabled workers left paid employment to apply for disability transfer programs, where they perceived the acceptance standards to be relaxed.

Compared with nondisabled workers, a smaller proportion of disabled workers were employed after leaving their jobs. In the 1993 sample, only 55 percent of voluntary job changers with disabilities reported positive wages in all subsequent waves, compared with 66 percent of those without disabilities. This suggests that a higher proportion of disabled workers exited the labor force after a voluntary job change (perhaps to apply for disability benefits) or that disabled workers had greater difficulty finding new jobs. ${ }^{6}$

OLS Estimates of the Wage-Change Model. Table 2 displays coefficients from the wage-change model. The results show no significant overall difference in wage growth between disabled and nondisabled workers over the 20-month period in either the pooled or disaggregated equations.

In general, job changes have a negative impact on wage growth. In the pooled model, wage growth is slower for both voluntary and involuntary job changers than for job stayers, but the magnitude of the estimated coefficient is greater, in absolute value, for involuntary job changers.

There is no clear prediction regarding the relationship between disability status and wage growth following a job change. In the empirical results, the coefficient of the interaction term between disability status and involuntary job changes is unstable across years and only significant in 1993. The magnitude of the estimated coefficient is counterintuitive, suggesting that disabled workers who make involuntary job changes have faster wage growth than job stayers with disabilities. We view the 1993 results with caution, however, because the sample size is extremely small (only 72

\footnotetext{
${ }^{6}$ Coefficients of other explanatory variables in the job-change model suggest that women and AfricanAmericans experience somewhat different patterns of job mobility relative to the corresponding majority group than do disabled workers. Both women and disabled workers have relatively high rates of involuntary job changes, whereas African-Americans have significantly lower rates of involuntary changes than do whites. Most important, the patterns of job mobility for women and African-Americans were stable between 1990 and 1993, suggesting that something unique occurred in the labor market for workers with disabilities to increase their rate of voluntary turnover over the same time span.
} 
TABLE 2

Wage Change Effects of Job Changes and Disability Status

\begin{tabular}{lccc}
\hline \hline & Pooled $^{b}$ & $1990^{b}$ & $1993^{b}$ \\
Variables $^{a}$ & $(N=28,968)$ & $(N=15,910)$ & $(N=13,059)$ \\
\hline Disabled & -0.000 & -0.004 & 0.004 \\
& $(0.011)$ & $(0.014)$ & $(0.015)$ \\
Voluntary & $-0.027^{* *}$ & $-0.046^{* *}$ & -0.013 \\
& $(0.010)$ & $(0.013)$ & $(0.015)$ \\
Voluntary* disabled & -0.059 & 0.006 & $-0.133^{* *}$ \\
& $(0.032)$ & $(0.044)$ & $(0.048)$ \\
Involuntary & $-0.049^{* *}$ & $-0.058^{* *}$ & -0.034 \\
& $(0.012)$ & $(0.014)$ & $(0.019)$ \\
Involuntary* disabled & 0.040 & -0.019 & $0.116^{*}$ \\
& $(0.037)$ & $(0.049)$ & $(0.058)$ \\
Change in marital status & $0.052^{* *}$ & $0.046^{* *}$ & $0.058^{* *}$ \\
& $(0.012)$ & $(0.015)$ & $(0.018)$ \\
Change in spouse's & -0.004 & -0.005 & -0.002 \\
employment status & $(0.009)$ & $(0.012)$ & $(0.013)$ \\
Year 1993 & $0.087^{* *}$ & - & - \\
& $(0.005)$ & & \\
\hline
\end{tabular}

${ }^{a}$ The dependent variable in the regressions is the change in log real wages between the start and end dates, where the end date is 20 months after the first interview. Descriptive statistics for the independent variables are available from the authors.

${ }^{b}$ Standard errors are shown in parentheses. In 1990, there are $1011(12,447)$ job stayers, $119(1256)$ voluntary changers, and 96 (980) involuntary changers in the disabled (non-disabled) sample. In 1993, there are $948(10,328)$ job stayers, 107 (1040) voluntary changers, and 72 (564) involuntary changers in the disabled (nondisabled) sample.

* Significance at the 0.05 level or better.

**Significance at the 0.01 level or better

SOURCE: SIPP, 1990 and 1993 (waves III-VIII).

involuntary job changers with disabilities), and the sign and significance levels are not robust across different specifications of the model.

In the case of voluntary job changes, the empirical estimates provide some evidence that wage growth is slower for disabled workers than for nondisabled workers. In the 1993 sample, wage growth following a voluntary job change was 13.3 percent slower for disabled workers than for nondisabled workers. The results are consistent with the hypotheses that disabled workers receive lower wage offers than do nondisabled workers either because of discrimination or limitations on job search or because disabled workers are more likely to leave jobs voluntarily because they have overestimated their productivity.

It is unclear why the negative effects of disability on wage growth following a voluntary job change appear only in 1993, when the ADA was expected to reduce discrimination and open new opportunities for workers 
with disabilities. The ADA could, however, lead to a higher rate of voluntary turnover under the job-mismatch hypothesis if the ADA gives disabled workers the opportunity to compete for more demanding jobs than would have been open to them in the past. While many disabled workers will be able to meet the increased demands, particularly with reasonable accommodations, it is also likely that more mistakes will be made and that some disabled workers will depart voluntarily for less demanding jobs.

\section{Summary and Discussion}

The most pronounced difference in patterns of job mobility between disabled and nondisabled workers is the higher rate of involuntary turnover among disabled workers. The finding is consistent with the theory that disabled workers, like other minority groups, comprise a secondary labor force that is last hired and first fired. This, together with the strong negative attitudes documented against specific health conditions and the relatively high proportion of charges of discrimination in job terminations filed under the ADA (Moss et al. 1999), might lead one to conclude that discrimination accounts for the higher rates of involuntary turnover among disabled workers. Our empirical test comparing turnover rates for workers with health conditions subject to different degrees of prejudice does not support the discrimination hypothesis, however. The higher rates of involuntary turnover among disabled workers are also consistent with a job-mismatch hypothesis if we assume that turnover results from poor job matches and that employers and workers have greater difficulty making good matches when a worker is disabled.

We find only weak evidence of differences in the wage effects of job changes between disabled and nondisabled workers. The findings are consistent with previous studies of wage discrimination concluding that low employment rates are a more serious problem than low wages for workers with disabilities (Baldwin and Johnson 1994, 1995, 2000). The results of this study, together with previous research and data on charges filed with the EEOC, suggest that disability advocates should focus on the dual problems of gaining access to employment and retaining employment in their efforts to obtain equal opportunities for disabled persons in the labor market.

The relatively small differences in mobility patterns and associated wage changes between disabled and nondisabled workers are not so surprising as they may first appear. Our sample is restricted to persons who are able to find employment, so we are omitting the most severely disabled persons from the analysis. The results suggest that, conditional on being able to 
work and being able to find a job, there are relatively few significant differences in job mobility patterns between disabled and nondisabled workers. It is highly likely that the real difficulty for disabled workers occurs in the initial employment search. Once employed, disabled workers are not so different from nondisabled workers.

\section{REFERENCES}

Baldwin, Marjorie L., and William G. Johnson. 2000. "Labor Market Discrimination Against Men with Disabilities in the Year of the ADA." Southern Economic Journal 66(January): 548-66. and _. 1995. "Labor Market Discrimination Against Women with Disabilities." Industrial Relations 34(October):555-77. and _ 1994. "Labor Market Discrimination Against Men with Disabilities." Journal of Human Resources 29(Winter):1-19.

Moss, Kathryn, Michael Ullman, Barbara Starrett, Scott Burris, andMatthew C. Johnsenn. 1999. "Outcomes of Employment Discrimination Charges Filed Under the Americans with Disabilities Act." Psychiatric Services 50(August):1028-35.

Royal, George P., and Michael C. Roberts. 1987. "Students' Perceptions of and Attitudes toward Disabilities: A Comparison of Twenty Conditions." Journal of Clinical Child Psychology 16(June): $122-32$.

Ruhm, Christopher J. 1991. "Are Workers Permanently Scarred by Job Displacements?" American Economic Review 81(March):319-23.

Social Security Administration. 2001. "Selected Data from Social Security's Disability Program." Unpublished table from the Office of the Chief Actuary (April 18), Washington.

Westbrook, Mary T., Varoe Legge, and Mark Pennay. 1993. "Attitudes Towards Disabilities in a Multicultural Society." Social Science and Medicine 36(5):615-24. 